\title{
Water Management Strategies for Urban Trees in Dry Environments: Lessons for the Future
}

\author{
Peter Symes and Geoff Connellan
}

\begin{abstract}
The maintenance and expansion of urban forests is a major challenge in periods of low rainfall and restricted availability of appropriatequality water sources for trees. The recent drought in eastern Australia has highlighted the need for innovation and new approaches to ensure tree health is preserved. Responses adopted by the Royal Botanic Gardens Melbourne and others have involved investigations into species more suited to changing climate conditions, assessment of tree and landscape water demand, understanding the hydrology of the site, effective irrigation delivery, management of the soil reservoir to optimize harvested stormwater, and provide soil water reserves for future high demand summer periods.

Key Words. Australia; Crop Coefficients; Drought; Royal Botanic Gardens Melbourne; Tree Watering; Soil Moisture Sensors; Urban Forest.
\end{abstract}

Management of tree health in Melbourne is an increasing challenge when confronting unprecedented drought conditions, water restrictions, community expectations to conserve water, and bouts of extremely high temperatures. Climate change projections for the Port Philip catchment (which includes Melbourne, Australia) indicate less than average rainfall and higher temperatures in the long term. The study area is located in the southeastern region of the Australian continent. Complicating water supply issues, increases in annual mean temperatures are anticipated to threaten the health and survival of trees adapted to previously cooler conditions. Careful planning is required to assist the transition from a dominance of over-mature and unsuitable tree populations to a more resilient urban forest under future conditions. The Royal Botanic Gardens Melbourne (RBG) and local governments have a range of obligations, including conservation of cultural heritage and delivery of environmental cooling benefits, to maintain trees and historic landscapes, which often require supplementary watering, at a time of projected climate stress and water scarcity.

In developing management strategies for urban trees experiencing dry conditions it is important to recognize the potential reasons for low soil moisture stress. These include:

- $\quad$ species not climatically suited to site

- restricted root systems-small soil volume and limited opportunity for root extension

- compacted soils-reduced water infiltration and limited gaseous exchange

- $\quad$ poor soil structure and low fertility (e.g., low organic content)

- $\quad$ site physical constraints limit opportunity to utilize rainfall-foliage interception, mulch absorption

- mechanical damage of roots and tree crowns
This paper outlines the strategies that are considered to be required to achieve sustainable urban trees and landscapes. These strategies are:

a. species selection to suit drier, higher demand and lower water availability climates, including increased frequency of extreme temperatures

b. determination of plant water demand using site-specific crop coefficients

c. understanding site hydrology, including effectiveness of precipitation and foliage interception

d. effective delivery of irrigation water using real-time multiple layer soil moisture sensing to aid scheduling

e. management of soil moisture, including deep soil water storage to optimize stormwater

\section{SITE CONDITIONS}

\section{Potential Climate Change Impacts}

Climate change models are generally following higher emission scenarios or the projected changes are happening more quickly than formerly predicted (Steffen 2009). These changes include the threat of recurring extreme events, such as acute bushfires, droughts, heat waves, floods, and drying trends (CSIRO 2008; Climate Change in Australia 2009). While there are still uncertainties about the extent of the main processes driving serious impacts, most of these ambiguities are still heading towards more rapid and serious climate change (Climate Change in Australia 2009; Steffen 2009).

Among the primary threats to health of urban forests and tree collections are changes to temperature regime and the subsequent physiological stresses on taxa better suited to cooler cli- 
mates (Kozlowski and Pallardy 1997; Hawkins et al. 2008). Some recent models applying a global temperature increase of $2^{\circ}-3^{\circ} \mathrm{C}$ are projecting that over the next century, up to $50 \%$ of vascular plant species could be threatened with extinction (Bramwell 2007). This risk should also be contemplated for urban forests.

In Victoria, climate change over the coming decades is anticipated to result in increased temperatures; drier conditions and increased frequency in severe events, such as extreme rainfall, bushfires, and droughts (CSIRO 2008), and most of these events are also common to the rest of southeast Australia (Suppiah et al. 2006; CSIRO 2008; CSIRO 2010). For Melbourne, it is expected that by 2070 under a lower greenhouse gas emission growth scenario, it will be $1.3^{\circ} \mathrm{C}$ warmer with $6 \%$ less rain, while under a higher greenhouse gas emission growth scenario it will be $2.6^{\circ} \mathrm{C}$ warmer with $11 \%$ less rain (out of a range of $-6 \%$ to $-24 \%$ ) (CSIRO 2008). The greatest increases in temperature are expected during summer, while the greatest rainfall reductions are projected during winter to spring, from $-11 \%$ to $-21 \%$ respectively (CSIRO 2008).

The potential impact of reduced rainfall on urban vegetation is well illustrated by considering the cumulative deficiency in rainfall, relative tolong-term averages, overextended dry periods (Figure 1).

Melbourne's mean annual average temperature is $15^{\circ} \mathrm{C}$. Many trees species grown in Melbourne (e.g., Acer, Betula, Platanus, Prunus, Quercus, and Ulmus) commonly occur in cities around the

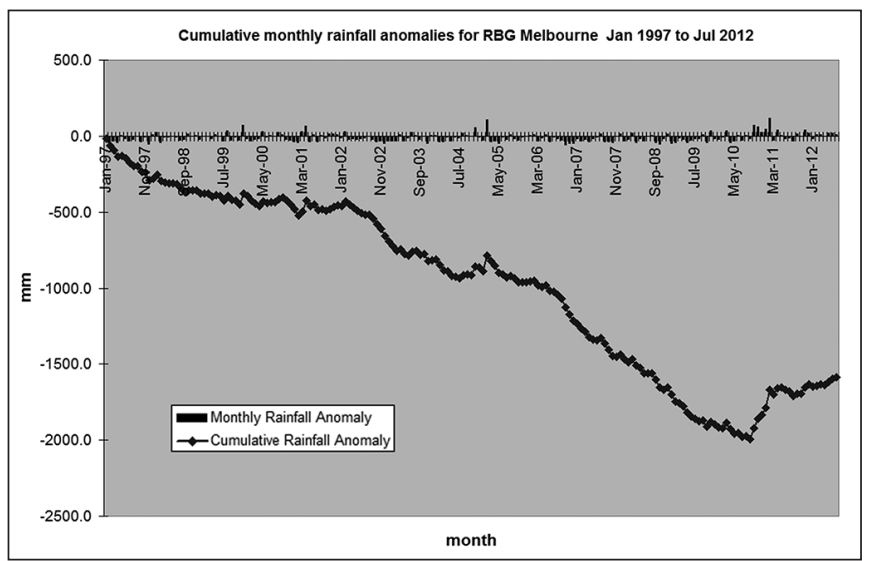

Figure 1. Cumulative monthly rainfall anomalies for RBG Melbourne January 1997 to July 2012. Note: This shows a cumulative trend of monthly rainfall anomalies compared to average monthly values from 1997 to 2012. There was steady decline during what is known as the Millennium Drought in Australia, from 1997 to early 2010. The cessation of the drought followed two La Niña events (often result in above average rainfall for eastern Australia) during 2010-2012, but these were not adequate to return the status to an equilibrium, even though the 2010-2011 La Niña event was unprecedented in its high strength and high amounts of rainfall since records began in Australia.

world, with mean annual temperatures ranging from about $10^{\circ} \mathrm{C}$ to $13^{\circ} \mathrm{C}$ (Kendal 2011). It is conceivable that some of these taxa are already experiencing significant heat stress, particularly with summer extreme temperatures. It is likely that an overall increase in annual average temperature by $1^{\circ}-3^{\circ} \mathrm{C}$ (notwithstanding temperature extremes compounded by urban heat island effects will place many of these species outside their viable cultivation range.

The impact of climate change and urbanization is likely to expose some plantings, for example street trees, to elevated temperatures. The influence of the urban heat island effect, increased thermal mass and reduced surface permeability of urban sites will contribute to temperature extremes (Coutts et al. 2007).

Rainfall is projected to change, in Melbourne region, by 2070 with average reductions of $11 \%$ to $21 \%$, for winter and spring respectively (CSIRO 2008). This can impact on the volume of stormwater harvested for irrigation purposes. There appears to be an amplification relationship between rainfall reductions and runoff of up to 1:3 (Howe et al. 2005). For example a $21 \%$ reduction in winter rainfall may translate into a $63 \%$ reduction of stormwater flow. Or in another case, the projected $7 \%$ reduction in summer rainfall may return a $21 \%$ reduction in stormwater harvest at a time of year when it is most needed (CSIRO 2008).

\section{Tree and Landscape Microclimate}

Microclimate mapping within the landscape is one approach that can assist with informed tree selection and the development of urban forests. This includes establishing the characteristics of both the edaphic (soil) and atmospheric environments throughout the year. For example, the edaphic environment for a deciduous arboretum will likely contain a higher moisture status during the tree's dormancy. The converse may occur during the tree's active growth period. Microclimate mapping is useful for establishing generic zones within the landscape. Yet, there is still even greater variation involved, even at small units of area. To illustrate, the study of the amount of rain penetrating through overhead tree canopy (throughfall) and corresponding soil moisture levels in the RBG Melbourne has revealed significant variation even at sub-meter spacing. In natural habitats, plants would only typically establish in niches suited to their recruitment and growth.

However, in contrived landscapes, the establishment period and planting site is often chosen to match amenity and functional criteria and this may not be the best match to the environmental conditions. Seasonal soil moisture or the soil water balance is one of the critical factors, and researchers need to develop and improve specific approaches of examining and monitoring point levels of soil moisture in respective landscape zones. This can be achieved in a technologically advanced way by using soil moisture sensors, or by physically examining soil cores or excavating pits, to compare moisture status against standardized methods. While this can be effective, it is usually less practical and more resource intensive, especially when regularly surveying sites across an entire urban forest planting. A simple matrix can be generated using variables - such as sun-shade, dry-moist, or cool-warm - to classify and map areas within the urban forest, to then guide tree selection and planning for the future (Figure 2).

\begin{tabular}{|c|c|c|c|}
\hline \multirow[b]{2}{*}{ SUN } & DRY $\longleftarrow$ & $\Rightarrow$ MOIST & \multirow[b]{2}{*}{ WARM } \\
\hline & Sun/Dry/Warm & Sun/Moist/Warm & \\
\hline & Sun/Dry/Cool & Sun/Moist/Cool & \\
\hline & Shade/Dry/Warm & Shade/Moist/Warm & \\
\hline SHADE & Shade/Dry/Cool & Shade/Moist/Cool & $\mathrm{COOL}$ \\
\hline
\end{tabular}

Figure 2. Simple microclimate matrix. Note: Plant selection for the RBG is becoming more focused towards the dry/warm quadrant of the matrix. Some trees from natural habitats in the moist/ cool quadrant, such as wet montane forests of southeastern Australia, are already showing signs of stress and some have been removed due to irreversible decline. 


\section{Soil Surveys}

Comprehensive soil surveys (Van Rees et al. 1993) are also an important part of the landscape planning process. Soils are the foundation of existence for so many life forms, and yet often they are taken for granted, or poorly studied or understood, in the urban landscape. In many landscape projects, the emphasis is on planning the hard landscape structures, services, and infrastructure, but when it comes to soil analysis and design, planning is inadequate or sometimes non-existent. It would not bear contemplation to request a civil engineer to avoid measuring the bearing capacity of a soil for a building, or cutting corners in safety specifications for structural integrity under varying conditions. The same importance must be placed on soils. Performance specifications, structural integrity, and long-term sustainability are also the language of robust landscape soils, and this is best informed by soil surveys.

Soil properties that should be considered primarily in relation to water management of trees include:

a. bulk density and soil strength

b. porosity, total water holding capacity, and plant available water (including soil moisture release curve)

c. particle size analysis (to determine risk of compaction)

d. soil texture and structure

e. infiltration rates and hydraulic conductivities (for both topsoil and subsoil)

f. sodium absorption ratio (to determine risk of soil particle dispersion (poor drainage and aeration) from water supplies containing more sodium.

g. electrical conductivity (to determine risk from the use of more saline water supplies)

Although very challenging, developing a better understanding of the biochemical and physical characteristics of the site soil are crucial for informed tree management.

\section{Tree Selection for Dry Sites}

Any assumptions about taxa adapted to periods of aridity need to be reassessed against projected climatic changes. For example, in Australia, there is a strong interest in Mediterranean flora on the assumed basis that these species are drought tolerant due to months of very minimal rainfall, particularly over the summer, in their natural habitat (Dallman 1998; Peel et al. 2007). However, Mediterranean climates are usually characterized by significant winter precipitation (Dallman 1998; Peel et al. 2007), which may also recharge groundwater and subsoil moisture levels. Phreatophytes are plants that either rely on or access ground water for their needs (Sommer and Froend 2011) and can be found in Mediterranean climates both in Australia (Sommer and Froend 2011) and California (Mahall 2009). Californian oaks, such as Quercus agrifolia (coast live oak) and Q. lobata (valley oak), are considered to be phreatophytes (groundwater-using) that have the capacity to tap groundwater for survival over drought periods (Mahall 2009). Specifically, Quercus lobata has been reported to access moisture from depths as great as 24 meters (Howard 1992). In European Mediterranean climates, David et al. (2007) studied Quercus ilex ssp. rotundifolia (holm oak) and Q. suber (cork oak) in southern Portugal and found that more than $70 \%$ of the trees' transpiration was sourced from groundwater at 4-5 m depths. Projections of climatic changes for Melbourne indicate a significant reduction in winter-spring rainfall (CSIRO 2008), which can increase the risk of reducing subsoil and groundwater moisture reserves for Mediterranean-climate-adapted trees.

In terms of current water management for trees, it can be useful to use simple graphing techniques to compare the range of trees that are within or outside typical annual precipitation ranges. Graphical summaries of a study of the annual precipitation requirements of some trees growing in the RBG Melbourne showed a significant rainfall deficit between the annual minimum rainfall requirement and the mean rainfall during 1999-2011, of $544 \mathrm{~mm}$, for the site. Figure 3 shows the rainfall deficiency, minimum annual rainfall requirements compared to mean rainfall, for a selection of 34 eucalypts growing at the site. Figure 4 shows the deficiency, graphed in increasing annual rainfall requirement, for more than 80 Australian native species. The difference may be up to $750 \mathrm{~mm}$ for some individual species. While some of this deficit is currently being met by artificial precipitation (irrigation), the RBG has set an upper baseline target of $900 \mathrm{~mm}$ per year for combined rainfall and irrigation amounts. It is unlikely that this could be sustained into the long term against current climatic projections and resource availability. As a baseline, tree selection should incorporate water requirements that are within the typical annual rainfall requirements for the proposed site including some variation for climatic change and low rainfall years such as decile 1 , or lowest $10 \%$ events.

\section{LANDSCAPE PLANTING WATER DEMAND}

\section{Trees and Landscape Planting Water Demand Estimation}

Evolution of irrigation scheduling in urban landscapes has progressed from time-based programming to a more sophisticated application of a greater spread of inputs, such as climatic data, evapotranspiration estimation methodologies, soil moisture sensing, and increasing knowledge of plant performance. However, plant water use in the urban landscape is still considered to be inadequately understood (Symes et al. 2008). Furthermore, a greater emphasis on water use efficiency and the insecurity of water supply presented by greater regulation and restrictions has increased the interest in priority setting of water allocation. This preferential irrigation is usually based on the perceived values or expectations of quality given to different areas or components of the urban forest. The setting of subjective quality standards in urban horticulture has generally been a vexing and contentious dilemma, let alone linking these standards to irrigation scheduling for various landscape performance levels.

There are various methodologies for estimating plant evapotranspiration (ETc). Two terms that are commonly used are Crop Factors (CF) and Crop Coefficients (Kc) (Allen et al 1998; Connellan and Symes 2006).

Plant water demand expressions use a reference evaporation value together with the crop adjustment factor to estimate the water use rate. The following expressions are used:

[1] $\quad \mathrm{ET}_{\mathrm{c}}=$ Crop Coefficient $\left(\mathrm{K}_{\mathrm{c}}\right) \times$ Reference Evapotranspiration $\left(\mathrm{ET}_{\mathrm{o}}\right)$

[2] $\quad \mathrm{ET}_{\mathrm{c}}=$ Crop Factor $(\mathrm{CF}) \times$ Pan Evaporation $\left(\mathrm{E}_{\mathrm{pan}}\right)$ 


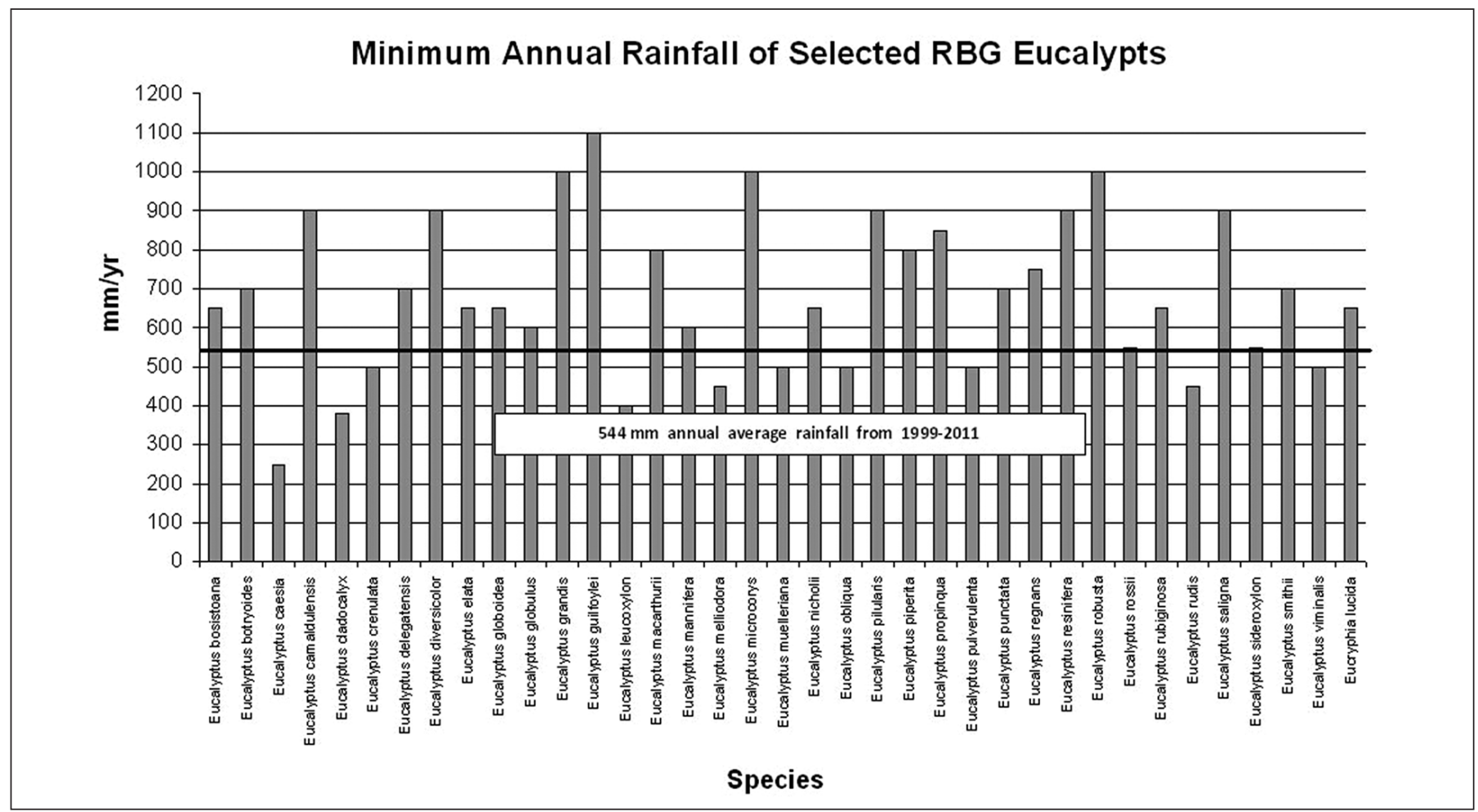

Figure 3. Minimum annual rainfall of selected RBG Melbourne eucalypts. Note: There are misconceptions in Australia that all Eucalypts are drought hardy. It has been the RBG experience that some Eucalypts in this list have exhibited what is considered to be decline from water stress even in areas where supplementary irrigation is applied. Seasonality of rainfall is another factor with some of these species normally experiencing summer maximum rainfall in their natural habitats.

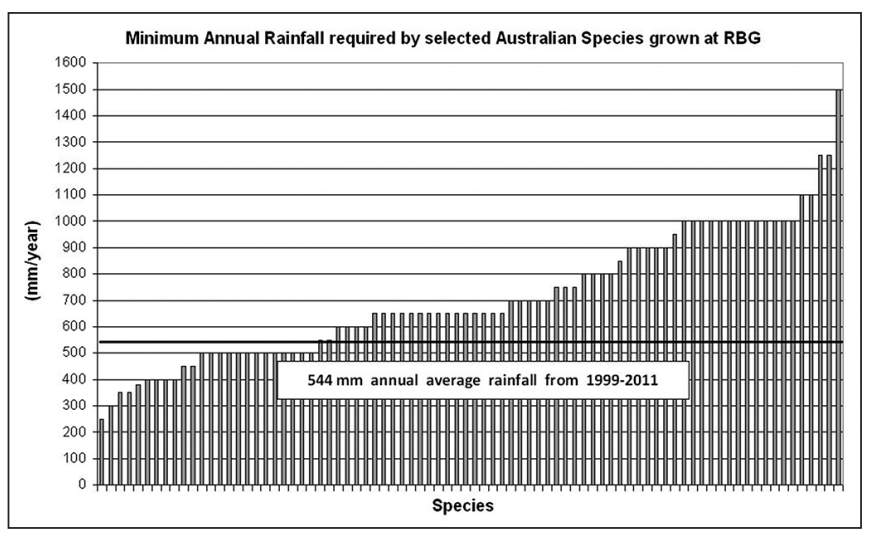

Figure 4. Minimum annual rainfall requirements for selection of Australian native trees at RBG Melbourne compared to mean rainfall for 1999-2011. Note: This chart shows the estimated minimum annual average precipitation requirements (sourced and adapted from Simpfendorfer 1992 and Boland et al. 2006) for a range of trees growing in the RBG. The bolded horizontal line shows the actual average annual rainfall of $544 \mathrm{~mm}$ recorded during 19992011 for the RBG. Bars that are above this line may demonstrate individual species that are at risk from longer term water deficits.

These are plant specific expressions. However, complex landscapes are characterized by diverse vegetation with multiple root systems and canopy tiers coexisting within the same area. The development of the landscape coefficient methodology of estimating plant water use (Costello and Jones 2000;
Connellan and Symes 2006) seems better suited to diverse urban landscapes, and this system is the basis for irrigation scheduling training currently endorsed by Irrigation Australia, a national body representing the irrigation industry. The landscape coefficient methodology (Costello and Jones 2000) incorporates reference evapotranspiration $\left(\mathrm{ET}_{\mathrm{o}}\right)$, a landscape coefficient $\left(\mathrm{K}_{\mathrm{L}}\right)$, plant species factor $(\mathrm{ks})$, microclimate factor $\left(\mathrm{km}_{\mathrm{c}}\right)$, and vegetation density factor $(\mathrm{kd})$ to estimate Landscape Evapotranspiration $\left(\mathrm{ET}_{\mathrm{L}}\right)$ and is summarized as follows:

$$
\text { [3] } \mathrm{ET}_{\mathrm{L}}=\mathrm{K}_{\mathrm{L}}(\mathrm{ks} \times \mathrm{kmc} \times \mathrm{kd}) \times \mathrm{ET}_{\text {o }}
$$

This methodology does not include prerogatives such as managing water resources in times of scarcity when levels of performance or priorities often have to be determined. Deriving levels of desired landscape performance (Connellan and Symes 2006) has been a water management topic in Australia for over a decade and is described further.

\section{Plant Condition and Water Requirements}

Assigning levels of quality or priorities help complete the development of the irrigation schedule. Alternatively, quality ranking in this context can be considered through the amount of water stress that is allowed for particular landscape areas. For instance, areas that were managed in a lush fashion would normally be subjected to only very low levels of water stress (unless waterlogged), while areas not irrigated at all would be subject to very high stress (unless adapted to local climate) (Connellan and Symes 2006). The RBG has developed an 
Table 1. RBG Melbourne Landscape Coefficient classification.

\begin{tabular}{|c|c|c|c|c|c|c|}
\hline & \multicolumn{4}{|c|}{ Landscape Coefficient $\left(\mathrm{K}_{\mathrm{L}}\right)$} & \multicolumn{2}{|c|}{ Examples for high scheduling requirement } \\
\hline & Rank & $\begin{array}{l}\text { Sche } \\
\text { Low }\end{array}$ & $\begin{array}{l}\text { ing rec } \\
\text { Med }\end{array}$ & $\begin{array}{r}\text { rement } \\
\text { High }\end{array}$ & $\begin{array}{l}\text { Median January water } \\
\text { requirement }(\mathrm{mm})\end{array}$ & $\begin{array}{l}\text { Examples of RBG landscape } \\
\text { zones/plant collections }\end{array}$ \\
\hline $\begin{array}{l}\text { Landscape } \\
\text { priority }\end{array}$ & $\begin{array}{l}\text { A } \\
\text { B } \\
\text { C } \\
\text { D }\end{array}$ & $\begin{array}{l}0.4 \\
0.4 \\
0.3 \\
0.2\end{array}$ & $\begin{array}{l}0.5 \\
0.5 \\
0.4 \\
0.3\end{array}$ & $\begin{array}{l}0.6 \\
0.5 \\
0.4 \\
0.3\end{array}$ & $\begin{array}{l}102 \\
82 \\
62 \\
41\end{array}$ & $\begin{array}{l}\text { Montane, rainforest collections } \\
\text { General collections } \\
\text { General landscape } \\
\text { Low-priority landscape }\end{array}$ \\
\hline
\end{tabular}

Note: This shows how the application of landscape coefficients were determined using a combination of landscape priorities and scheduling requirement to derive a value for the summer months. Two examples are provided that follow: The rank of Landscape Priority 'A' combined with a Scheduling Requirement of 'High' results in a landscape coefficient of $\mathrm{K}_{\mathrm{L}} 0.6$ to be applied. This results in a median January water requirement of $102 \mathrm{~mm}$ for a Rainforest Plant collection.

A Landscape Priority 'D' site combined with a Scheduling Requirement of 'Low' results in a landscape coefficient of $\mathrm{K}_{\mathrm{L}} 0.2$ to be applied. This results in a median January water requirement of $41 \mathrm{~mm}$ for a low-priority landscape area.

irrigation scheduling framework based on the landscape coefficient methodology (Costello and Jones 2000) and included landscape priority levels (Table 1). The implementation of this framework has resulted in improved water distribution to areas of different requirements without increasing overall water consumption. Indeed, the RBG has been able to maintain an overall reduction in potable water use of $40 \%-50 \%$ since 1994-1995 (when improvements to water management were initiated) (Royal Botanic Gardens Melbourne 2011), over 13 years of unprecedented drought conditions for Melbourne.

\section{Determination of Site-specific $K_{L}$}

Recent studies have been undertaken in the RBG to estimate actual landscape coefficients through the use of capacitance soil moisture sensor technology and a site reference Automatic Weather Station (AWS) (Symes et al. 2008). At one study site comprised of mixed landscape planting, a site-specific calibration of the sensor technology was carried out. Calibration of soil moisture sensors was required to provide greater accuracy of measurement to quantify water movement in the soil volume. The standard method, based on gravimetric sampling, was used in the site calibration. The calibration procedure was carried out according to the Calibration Manual for Sentek Soil Moisture Sensors (Anonymous 2011) procedures. Soil samples were taken immediately adjacent to an installed sensor assembly tube. Soil moisture content and bulk density were determined in a soils laboratory. A calibration polynomial equation was developed for each representative soil layer. The correlation between soil sensor readings and soil moisture was determined to be $\mathrm{r}^{2} 0.97$ for the sandy organic loam in the 10-20 $\mathrm{cm}$ layer and $\mathrm{r}^{2} 0.80$ for the sandy loam in the $30-50 \mathrm{~cm}$ layer.

Average monthly values for landscape coefficient values were calculated for $0-50 \mathrm{~cm}$ soil profile depth using soil moisture data from capacitance soil moisture sensors and calculated ETo from the RBG AWS. These values ranged from $K_{L} 0.11$ (winter) to $K_{L}$ 0.41 in late summer/early autumn compared to RBG estimated values of $K_{L} 0.25$ for winter to $K_{L} 0.5$ for summer that would normally be assigned to this (and similar other garden beds). [See Figure 5 - Measured site specific monthly landscape coefficient $\left(\mathrm{K}_{\mathrm{L}}\right)$ values for research site RBG5A]. Using the landscape coefficient methodology advocated by Costello and Jones (2000), the summer landscape coefficient was calculated to be $\mathrm{K}_{\mathrm{L}} 0.65$. There are clear opportunities presented to apply data from soil moisture sensing and an AWS to improve irrigation scheduling in matching the seasonal demand and actual water requirement.

\section{RAINFALL EFFECTIVENESS}

In the RBG Melbourne, a study of the shifts in the localized trends of rainfall patterns, partitioning of rainfall (fate of rainfall), and rainfall effectiveness is being carried out in conjunction with Monash University, Melbourne. Measurements to date are finding event-based canopy interception rates from 60\%-80\% of rainfall (Dunkerley 2011).

Changes in the nature of sub-daily precipitation may result in increased precipitation losses via canopy interception and evaporation. Rainfall losses (reduced effectiveness) are more important, as a proportion, in small rainfall events. Understanding rainfall precipitation at higher levels of precision and smaller temporal scales is now recognized as an important part of adaptive management. Further, this research highlights the need to understand precipitation at higher levels of precision and smaller temporal scales in future adaptive management. Rainfall interception by upper tier vegetation canopies and mulch layers was a pertinent factor for all trial sites. Typically, rainfall only appeared effective in increasing soil moisture content if individual rain-

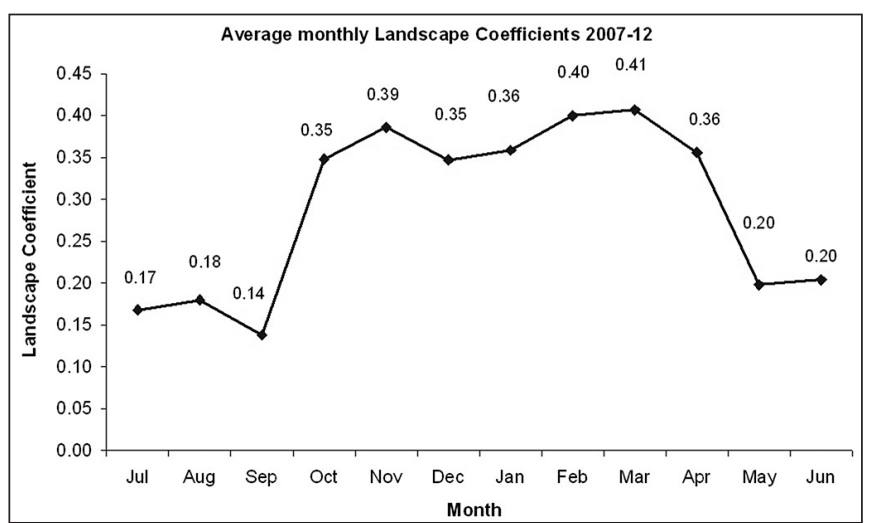

Figure 5. Monthly site specific landscape coefficient $\left(K_{L}\right)$ values for research site RBG5A - Viburnum Bed. Note: RBG5A - Viburnum Bed is study site based in a landscape planting comprising of multitiered vegetation strata with perennials, woody shrubs, and deciduous mature trees. The location has a northeasterly aspect (southern hemisphere), exposed to full sun for most of the day and periodic hot northerly winds in summer. This graph shows the range of estimated monthly average landscape coefficient values of this site for the period 2007-2012. These were estimated by comparing plant water use as indicated by calibrated soil moisture sensor readings with Penman-Monteith reference evapotranspiration from the RBG Automatic Weather Station. 
fall events were greater than $4-7 \mathrm{~mm}$ as measured by the RBG Automatic Weather Station. From July 2009 to June 2011, average canopy interception of total rainfall over the soil moisture sensor sites was $34 \%$ compared to AWS data. (Note: to reduce excessive labor in data collection, these measurements did not include daily amounts less that 2 $\mathrm{mm}$, so it is likely this is an underestimation of actual interception values due to the higher proportion of interception for smaller rainfall amounts.) Canopy interception values approaching $67 \%$ were measured for some important urban forest sites in the RBG. The variation of rainfall effectiveness for respective events and sites was also readily monitored and observed through soil moisture sensing. This reinforces the importance of applying an 'effective rainfall' factor in irrigation scheduling methodology (Symes et al 2008).

\section{IRRIGATION EFFICIENCY}

There are a multitude of techniques employed in irrigating trees, including sprinklers, sprays, bubblers, drip emitters, driplines, wells, and various perforated pipe distribution systems. The key issues are the area of root plate watered, depth of watering, infiltration effectiveness, soil water storage capacity, and total amount of water applied.

In the design and management of tree watering systems there are some key characteristics that should be considered.

\section{Effective Delivery - Deep Watering}

Deep watering, for example 200 to $500 \mathrm{~mm}$, is recommended for mature trees as the recharging of deeper soil layers can enhance tree resilience, particularly during periods of drought. This generally requires long run times-hours not minutesand slow application rates, if drip emitters are being used.

Water will only move down the soil profile under saturated conditions. This requires the wetting of the shallower soil layers prior to the deeper layers being wet. In some situations, the placement of the delivery outlets (e.g., subsurface drip, wells) deep into the soil profile can be used to overcome the need for watering of the top soil layers. This strategy reduces the competition for water between shallow rooted vegetation and the tree.

\section{Dripline Systems}

Many dripline systems, as well as sprays, are currently only applying water in the top $100 \mathrm{~mm}$ to $150 \mathrm{~mm}$ of the soil. Delivery using close emitter spacing interval, for example $300 \mathrm{~mm}$ apart, low-flow-rate drippers (e.g., $1.5 \mathrm{~L} / \mathrm{h}$ ), for relatively short periods, is not ideal for trees. The ideal drip delivery would be wide spacing, for example $0.5 \mathrm{~m}$ or more, with higher flow rates, providing soil infiltration and percolation capacity is adequate, so that deep soil wetting can be achieved.

\section{Zoning of Irrigation}

The ability to control the application of water to areas of vegetation or single large plants (trees) is essential, in terms of achieving effective watering and efficiency. In the design of irrigation systems, the areas containing tree roots should be identified and the water delivery control arranged so that the specific water requirements of that area can be satisfied, without necessarily watering adjacent vegetation or areas. Zoning of tree watering is essential and is sometimes required to comply with water restriction conditions.

Strategies to achieve high water-use efficiency in the irrigation of urban trees are outlined in Connellan (2013).

\section{ROOT ZONE SOIL MOISTURE SENSING}

Soil moisture sensing is one complementary technological tool that can be used to provide a greater understanding of plant water use, and assess irrigation and rainfall effectiveness. Knowledge of the soil moisture content, and the response of plants to soil moisture conditions, is essential for precision scheduling of irrigation (Symes et al. 2008). The technology ranges from cost effective but simple equipment to highly sophisticated and expensive systems that are used more for research purposes or large-scale agricultural enterprises (Charlesworth 2000). Nevertheless, the information provides a useful insight into the physical (soil hydrology) and biological (plant water use) patterns under the soil surface and helps close the loop in landscape water management (Symes et al. 2008). It is improved when combined with meteorological measurement and professional judgment to help compensate for the high levels of landscape variability. RBG is currently in a partnership research project to quantify plant water use, including weather data and horticultural expertise (Symes et al. 2008). Apart from the immediate application to improve irrigation management, it is also anticipated that this research will assist in establishing baselines for understanding the influence of the current climate on plant water use, and assessing future trends that may develop.

\section{Soil Moisture Sensor Applications in Scheduling}

Knowledge of soil moisture content of plant response to soil moisture conditions is essential for precision scheduling of irrigation. The soil moisture level is typically determined using a predictive technique through ET estimation and conducting a soil water balance. Soil moisture sensing allows the actual value of soil moisture to be an input into the scheduling decision making process. The incorporation of soil moisture sensing in the control process as feedback makes this a true, closed-loop type of control.

Access to soil moisture data significantly expands knowledge of plant and soil water behavior. Identification of the time the soil moisture levels reach a set-point value, to initiate irrigation, is only one application of the technology.

The nature of the soil moisture data that can be obtained determines how it can be used. The number, location, and precision of sensors and frequency of readings are all important. Although a single sensor, positioned within the root zone and monitored on a daily basis, provides valuable information, the installation of multiple sensors greatly expands the knowledge base. The installation of multiple sensors at selected positions down the soil profile allows soil moisture in the different soil zones to be monitored and changes between zones to be analyzed. Continuous monitoring of sensors with access through the internet, in real time, provides the opportunity for enhanced analysis of the plant soil system.

Portable probes provide for assessment of variations in plant wateruse $(\mathrm{ETc})$ rates across the varioushydrozones of thelandscape. 
Graphical presentation of soil moisture data allows absolute values to be read as well as the changes in soil moisture conditions to be readily interpreted.

Examples of how soil moisture data can be used to provide a better understanding of aspects of the water management of complex landscapes include:

- identification of active root zones in the soil profile

- $\quad$ estimate of the Crop Coefficient $\left(\mathrm{K}_{\mathrm{c}}\right)$ value

- influence of water logged conditions on plant growth

- effectiveness of irrigation

- effectiveness of rainfall

- drainage characteristics of the soil

\section{Seasonal Adjustment of Site-specific Landscape Coefficients}

Based on the information shown by soil moisture sensing, RBG has now included seasonal differentials in its four scheduling regimes for garden areas: landscape coefficients are adjusted for winter, spring, summer, and autumn. This has reduced overwatering in the cooler times of the year, and particularly, the transitional periods from winter-spring-summer. For some areas, it was shown that under-watering occurred in the peak of summer that was difficult to remediate under current water scarcity and restrictions of Melbourne. The availability of soil moisture readings through the internet allows the actual soil moisture conditions to be monitored in real time and direct reference made to the condition of the plants. In periods of high temperatures and high evaporative demand this information allows informed water management decisions to be made. The soil moisture data generated allows key indicators to be used to aid in the water management of the landscape.

\section{SUBSOIL WATER STORAGE}

Subsoil Moisture Storage and Recovery is a methodology being developed through a research partnership among the RBG, Sentek Pty, Ltd., and the University of Melbourne to recharge subsoil moisture when the water is freely available as a reserve for trees. The severity of depletion of soil water reserves, over multiple dry years, is illustrated in Figure 4. Soil moisture sensing technology provides the means to study the effectiveness of the irrigation technique and the rate and depth of tree water use. This technique is being considered to optimize the use of stormwater, as this is usually more available in the late autumn-winter months when irrigation is not normally required. The concept is that stormwater is applied via irrigation to soil profiles in winter-spring to 'bank' water when stormwater supplies are more available (Figure 6), thus ensuring subsoil moisture is adequate for the forthcoming summer and to also minimize the use of potable water for irrigation. At study site 57, the graph shows soil moisture traces at each $10 \mathrm{~cm}$ layer of soil profile down to one meter depth under a specimen of Quercus aff. alba (Figure 7). It can be seen that water is not used at most depths during winter when the tree is dormant. However, after precipitation during July to August 2010, all layers of the soil profile including the subsoil have been recharged. The patterns of water extraction by the tree can be more easily seen from mid-December 2010 , with most intensive use in January 2011, especially for the deeper soil layers. These findings have led to the consideration of a split irrigation scheduling/water balance regime in the RBG. For example, the landscape coefficient $\left(\mathrm{K}_{\mathrm{L}}\right)$ for the top $30 \mathrm{~cm}$ in December was calculated to be $\mathrm{K}_{\mathrm{L}} 0.5$, but for the full profile it equated to $\mathrm{K}_{\mathrm{L}} 0.94$. This means the turf zone could be managed at lower $\mathrm{K}_{\mathrm{L}}$ values while the trees are using subsoil reserves, thus saving potable water during summer. Based on the methodology described by Harris (1998) and Kopinga (1998), modeling of tree water needs in the RBG suggest that if soil moisture was at full capacity and accessible to $1000 \mathrm{~mm}$ soil depths, then the average Gardens tree could subsist for about 90 days in summer with no additional precipitation. This potentially extends to 150 days when considering species more adapted to drought conditions. The application of Subsoil Moisture Storage and Recovery has the clear potential to maintain tree health in water-scarce environments, and minimize the use of supplementary potable water.

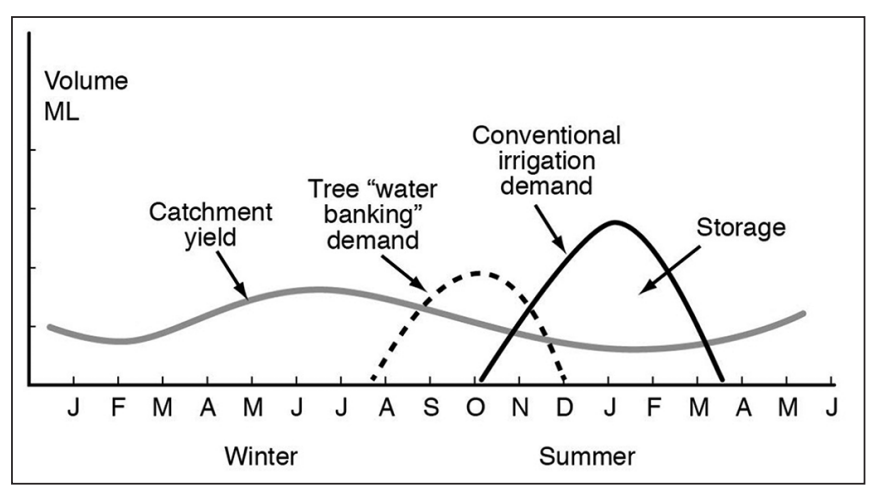

Figure 6. Schematic of typical stormwater availability and irrigation demand.

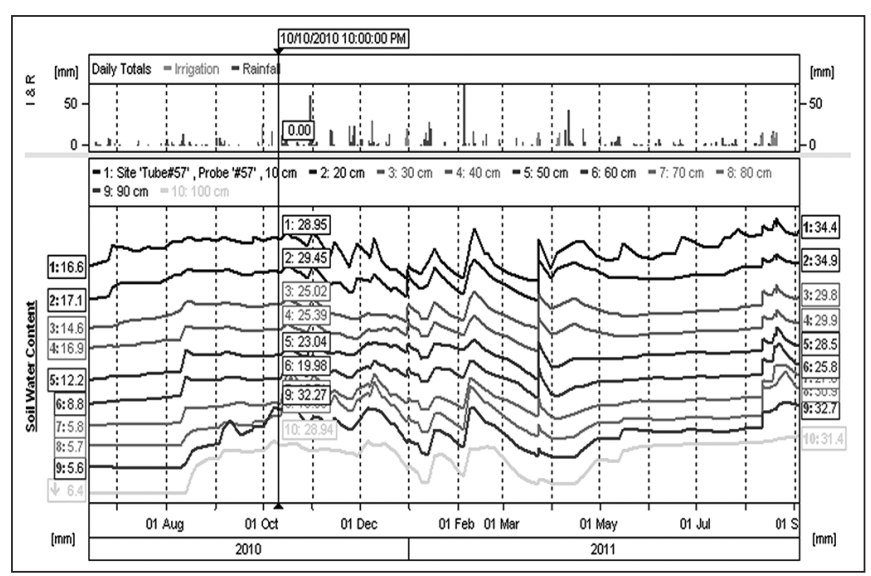

Figure 7. Soil moisture traces for the root-zone of Quercus aff. alba growing at RBG site 57 . Note: Figure 5 shows individual soil moisture traces $(\mathrm{mm} / 10 \mathrm{~cm})$ for the root zone of Quercus aff. alba at $10,20,30,40,50,60,70,80,90$, and $100 \mathrm{~cm}$ spacings from top to bottom in the graph. Previous to August 2010, soil moisture contents from $60 \mathrm{~cm}$ to $100 \mathrm{~cm}$ were at or below permanent wilting point. Recharging of soil moisture to $100 \mathrm{~cm}$ depth can be seen early on in August 2010. Tree water use is most visible to $100 \mathrm{~cm}$ depth from mid-December 2010 until late March 2011. The tree enters dormancy during April 2011 and soil profile begins recharging at this time. 


\section{RECOMMENDATIONS FOR HEALTHY AND DROUGHT-RESILIENT TREES}

The following are key water management strategies that are essential to achieving sustainable landscapes with trees:

- $\quad$ satisfy water requirements for healthy trees, not just for tree survival

- optimize soil environment to achieve resilient, healthy, and extensive root systems

- ensure site rainfall is fully utilized

- water deep (if required) to achieve wetting of soil profile at depths greater than $200 \mathrm{~mm}$

- water proactively rather than wait for signs or evidence of stress

- $\quad$ adopt "water banking" approach in soil, prior to high water-demand period

- $\quad$ recycled water quality should be checked for potential short- and long-term (accumulation) risks, such as toxicity or degraded soil health

- regularly check what is happening in the soil, sample it or use soil moisture sensors

- $\quad$ evaluate water delivery system hydraulically and in-soil water distribution performance

\section{CONCLUSION}

Experiences in the maintenance of urban forests during dry years have shown that a thorough understanding of the tree requirements and site conditions is essential to achieving a sustainable urban forest. The starting point is selecting the right species by taking into account the site's microclimate, special constraints, and the tree's desired functional performance.

Soil moisture sensors have proven to be very powerful tools in providing information about plant water use, soil water behavior, root system activity, and effectiveness of rainfall and irrigation. Measurement of net rainfall reaching the ground, following interception by the tree canopy, has also assisted in building the knowledge base necessary to successfully maintain trees.

A range of techniques have been developed and employed at RBG Melbourne to assist in the scheduling of irrigation and complex landscape plantings. These include site-specific and seasonally adjusted landscape crop coefficients, stress indicators to identify refill points, and soil water banking.

Acknowledgments. The authors wish to express their appreciation for the instrumentation expertise and data collection of Mr. Steven Liu, Curator Assistant, Environmental Horticulture, Royal Botanic Gardens Melbourne.

\section{LITERATURE CITED}

Allen, G.R., L.S. Pereira, D. Raes, and M. Smith. 1998. FAO irrigation and drainage paper 56: Crop evapotranspiration, guidelines for computing crop water requirements. Food and Agriculture Organization of the United Nations: Rome, Italy.

Anonymous. 2011. Calibration Manual For Sentek Soil Moisture Sensors Version 2.0, Sentek Pty, Ltd. Accessed 02/20/2013. <www.sentek.com.au/downloads/downloads.asp>

Boland, D.J., M.I.H. Brooker, G.M. Chippendale, N. Hall, B.P.M. Hyland, R.D. Johnston, D.A. Kleinig, M.W. McDonald, and J.D. Turner. 2006. Forest Trees of Australia, 5th edition. CSIRO Publishing. 768 pp.
Bramwell, D. 2007. The response of botanic gardens to climate change. BG Journal 4(2):3-8

Charlesworth, P. 2000. Irrigation Insights No. 1, Soil Water Monitoring. CSIRO Land and Water. Land and Water Australia: Canberra. 96 pp.

Climate Change in Australia. 2009. Science Update 2009 issue one. Accessed 11/10/2011. <www.climatechangeinaustralia.gov.au/resources.php>

Connellan, G.J. 2013. Water Use Efficiency for Irrigated Turf and Landscape. CSIRO Publishing, Collingwood, Victoria, Australia. 416 pp.

Connellan, G., and P. Symes. 2006. The development and evaluation of landscape coefficients to determine plant water requirements in the urban environment. In: Proc. of Irrigation Association of Australia Conference, May 2006, Sydney, Australia.

Costello, L.R., and K.S. Jones. 2000. A Guide to Estimating Irrigation Water Needs of Landscape Plantings in California. Sacramento, University of California Cooperative Extension, California Department of Water Resources. Accessed 10/02/2011. <www.water.ca.gov/ wateruseefficiency/docs/wucols00.pdf>

Coutts, A.M., J. Beringer, and N.J. Tapper. 2007. Impact of increasing urban density on Local climate: Spatial and temporal variations in the surface energy balance in Melbourne, Australia. Journal of Applied Meteorology and Climatology 46:477-493.

CSIRO. 2008. Climate Change in Victoria. Department of Sustainability and Environment, The State of Victoria, Melbourne, June 2008. Accessed 11/15/2011. <www.climatechange.vic.gov.au/publications>

CSIRO. 2010. Climate variability and change in south-eastern Australia: A synthesis of findings from Phase 1 of the South Eastern Australian Climate Initiative (SEACI). Accessed 11/15/2011. <www.seaci.org/ publications/documents/SEACI-1\%20Reports/Phase1_SynthesisReport.pdf>

Dallman, P.R. 1998. Plant life in the world's Mediterranean climates: California Native Plant Society, University of California Press: Berkeley and Los Angeles, California. 257 pp.

David, T.S., M.O. Henriques, C. Kurz-Besson, J. Nunes, F. Valente, M. Vaz, J.S. Pereira, R. Siegwolf, et al. 2007. Water-use strategies in two co-occurring Mediterranean evergreen oaks surviving the summer drought. Tree Physiology 27:793-803.

Dunkerley, D. 2011. Interception processes and rates on vegetation in a major urban area: Metropolitan Melbourne, Australia. Geophysical Research Abstracts Vol. 13 EGU 2011: 4016, 2011.

Harris, R. 1998. Irrigation of Newly Planted Street Trees. In: Proceedings of Conference on The Landscape Below Ground II, Second International Workshop on Tree Root Development in Urban Soils March 5-6, 1998. San Francisco, California. International Society of Arboriculture: Champaign, Illinois, U.S.

Hawkins, B., S. Sharrock, and K. Havens. 2008. Plants and climate change: Which future? Botanic Gardens Conservation International, Richmond, UK.

Howard, J.L. 1992. Quercus lobata. In: Fire Effects Information System, USA Department of Agriculture, Forest Service, Rocky Mountain Research Station, Fire Sciences Laboratory (Producer). Accessed July 2009. <www.fs.fed.us/database/feis >.

Howe C., R.N. Jones, S. Maheepala, and B. Rhodes. 2005. Implications of Potential Climate Change for Melbourne's Water Resources: CSIRO Urban Water and CSIRO Atmospheric Research and Melbourne Water, Melbourne, Victoria, Australia. 26 pp.

Kendal, D. 2011. Potential effects of climate change on Melbourne's street trees and some implications for human and non-human animals. In: Proceedings of 2011 State of Australian Cities Conference, Melbourne, Australia. 
Kopinga, J. 1998. Evaporation and Water Requirements of Amenity Trees with Regard to the Construction of a Planting Site. In: Proceedings of Conference on the Landscape Below Ground II, Second International Workshop on Tree Root Development in Urban Soils March 5-6, 1998. San Francisco, California. International Society of Arboriculture: Champaign, Illinois, U.S.

Kozlowski, T.T., and S.G. Pallardy. 1997 Physiology of Woody Plants 2nd edition. Academic Press, San Diego, California, U.S. 411 pp.

Mahall, B.E., C.M. Tyler, E.S. Cole, and C. Mata. 2009. A comparative study of oak (Quercus, Fagaceae) seedling physiology during summer drought in southern California. American Journal of Botany 96:751-761.

Peel, M.C., B.L. Finlayson, and T.A McMahon. 2007. Updated world map of the Köppen-Geiger climate classification. Hydrology and Earth System Sciences 11(5):1633-1644.

Royal Botanic Gardens Melbourne. 2011. Water Conservation webpage. Accessed 11/01/2011. <www.rbg.vic.gov.au/horticulture/environmental-management/water-conservation\#h_7>

Simpfendorfer, K.J. 1992. An introduction to trees for southeastern Australia. Revised Edition. Inkata Press, Sydney, Australia. 377 pp.

Sommer, B., and R. Froend. 2011. Resilience of phreatophytic vegetation to groundwater drawdown: Is recovery possible under a drying climate? Journal of Ecohydrolology 4:67-82.

Steffen, W. 2009. Climate Change 2009: Faster Change and More Serious Risks. Australian Government, Department of Climate Change. Accessed 11/01/2011. <www.anu.edu.au/climatechange/wp-content/ uploads/2009/07/climate-change-faster-change-and-more-seriousrisks-final.pdf $>$

Suppiah, R., B. Preston, P.H. Whetton, K.L. McInnes, R.N. Jones, I. Macadam, J. Bathols, and D. Kirono. 2006. Climate change under enhanced greenhouse conditions in South Australia: An updated report on assessment of climate change, impacts and risk management strategies relevant to South Australia. Climate Impacts and Risk Group, CSIRO Marine and Atmospheric Research.

Symes, P., G. Connellan, M. Dalton, and P. Buss, 2008. Developing water management strategies for complex landscapes. In: Proceedings of Irrigation Australia Conference: Melbourne Exhibition Centre, May 20-22, Irrigation Association of Australia: Melbourne.

Van Rees, H., A. Jackman, J. Williamson, and D. Cummings. 1993. Royal Botanic Gardens soil survey. Centre for Land Protection Research, Department of Conservation and Natural Resources: Bendigo, Victoria, Australia.

Peter Symes

Curator

Environmental Horticulture, Royal Botanic Gardens

Melbourne, Victoria, Australia

Geoff Connellan (corresponding author)

Honorary Fellow

Department of Resource Management and Geography

University of Melbourne, Victoria, Australia

geoffc@unimelb.edu.au
Zusammenfassung. Die Erhaltung und die Ausdehnung von urbanen Wäldern ist eine große Herausforderung in Zeiten von geringem Niederschlag und begrenzter Verfügbarkeit von angemessenen, qualitativen Wasserquellen für die Bäume. Die kürzliche Trockenheit in Ostaustralien hat den Bedarf für Innovationen und neue Ansätze zur Erhaltung von Baumgesundheit hervorgehoben. Die gewonnenen Antworten aus dem Königlich Botanischen Gärten in Melbourne und anderswo beinhalteten auch Untersuchungen der Arten, die mehr geeignet sind für Klimaveränderungen, Untersuchung des Baum- und Landschaftswasserbedarfs, Verständnis der Hydrologie des Standortes, effektive Durchführung der Bewässerung, Management der Bodenreserven zur Optimierung von gewonnenem Sturmwasser und erhalten Bodenwasserreserven für kommende Sommerperioden mit hohem Wasserbedarf .

Resumen. El mantenimiento y la expansión de los bosques urbanos son un reto importante en períodos de escasez de precipitaciones y poca disponibilidad de fuentes adecuadas de agua de calidad para los árboles. La reciente sequía en el este de Australia ha puesto de relieve la necesidad de innovación y de nuevos enfoques para asegurar la salud de los árboles. Las respuestas adoptadas por el Royal Botanic Garden de Melbourne, y otros que han participado, ha sido en la investigación de las especies más adaptadas a las condiciones cambiantes del clima, evaluación de los árboles, la demanda de agua para el paisaje, la comprensión de la hidrología del sitio, la entrega efectiva de riego, la gestión del almacenamiento del suelo para optimizar el agua cosechada por tormentas y así proporcionar reservas de agua del suelo para futuros períodos de alta demanda en el verano. 